\title{
Using a Transformative Paradigm Research Approach to Investigate Guidance and Counselling Service in Papua New Guinea Schools
}

\author{
Kainaro Kravia
}

Paul Pagliano

James Cook University

etropic 14.1 (2015): 98-110. http://www.reefandleaf.com.au/etropic.html \& http://www.jcu.edu.au/etropic

\begin{abstract}
Since the introduction of school guidance and counseling services in Papua New Guinea (PNG) schools in the 1970s little has changed. A limited number of Guidance Officers (GOs) each look after a large number of secondary schools. Consequently they only have time to administer a bank of Australian Council for Education Research (ACER) aptitude tests to grade 11 students and provide limited career guidance to year 12 students. This means that more than one million school aged children in PNG miss out on adequate guidance and counselling services, with any support they do receive being provided by untrained school personnel. This comparative study using a transformative paradigm research approach will explore guidance and counselling service in PNG and Australia with a particular focus on services available to schools in Goroka (PNG) and in Townsville (Queensland, Australia). Townsville has been identified as an ideal location because of Australia's political history and its legacies in many systems of government (including the education system), economic practices and social life in PNG. Another factor is the researcher's location as a post graduate student at the James Cook University in Townsville. The study will utilise a mixed methods comprising of autoethnography, survey, and interview. Through autoethnography the researcher intends to investigate his own experiences working in guidance and counselling services in PNG. Next is the use of a survey questionnaire to gauge care-givers' views about the scope and type of services currently provided in PNG and in Queensland schools. Finally, several pertinent individuals in PNG and the State of Queensland will be interviewed about guidance and counselling services in the respective countries with a view to exploring how services will need to change to better meet anticipated future requirements. The information is then distilled to make recommendations as to how guidance and counseling services in PNG schools might be transformed.
\end{abstract}

Keywords: Transformative research paradigm; comprehensive guidance and counselling services; autoethnography; guidance, counselling, 


\section{Introduction}

Good guidance and counselling becomes increasingly important as the contemporary education and employment related choices facing young people change and become more and more complex. Change and complexity arise not only from changes in jobs and career patterns, but also from the growing flexibility of pathways that link education to working life. Such changes and complexity constitute strong challenge to lifelong guidance and counselling. To meet challenges it is vital that guidance and counselling start as an early process assisting children and young people with active career planning and personal development (Collision \& Garfield, 2013; Noworol, 2011).

Guidance is the processes of helping people make important choices that affect their lives. The programs are designed to promote the development of personal competencies and interests in an individual to make meaningful educational and occupational decisions and to manage their individual life paths in learning, work and other settings in which these competences are learned and/or used (Friedel, 2011; Noworol, 2011). Counselling involves a professional relationship between a trained counsellor and a client designed to help the client make choices and solve problems (George \& Cristiani, 1995). The process empowers clients to become self-sufficient and discover their own solutions (Geldard \& Geldard, 2012). One distinction between guidance and counselling is that guidance focuses on helping individuals choose what they value and counselling focuses on helping them make the changes. A common misconception is that school counsellors only provide guidance, but in reality, guidance is only one part of the overall service provided by professional counselling (Gladding, 2000 in Friedel, 2001).

Having a comprehensive guidance and counselling programs in schools embrace all students with different learning needs to achieve academic success and to develop into contributing members of their societies. Furthermore, the programs enable students to articulate feelings of competence and confidence as learners, display a positive interest in learning, take pride in work and in achievement, and identify attitudes and behaviours which lead to successful learning (Gysbers \& Henderson, 2001).

PNG is a developing country with a short but highly complex and somewhat unstable political history and limited resources. It is confronted by highly pronounced issues, such as diverse cultural groupings, high illiteracy rates, very low income per capita and a very low human development index (UNESCO, 2011). The ratio of guidance officers to students is 1:14,000. Schools do not have trained counsellors; counselling services are provided by either churches or non-government organisations. It is therefore not realistically possible for the country to simply adopt the best guidance and counselling practices of developed countries in their entity. Therefore, the development of guidance and counselling services in PNG schools has to be developed to suit the local needs of the PNG population.

\section{Background to This Study}

The idea that student well-being is a school responsibility can be traced back to the early Greek philosophers and more recently to early C19 ${ }^{\text {th }}$ notions of pastoral care. Literature indicates that about 1910 in the United States of America (USA) vocational guidance started in isolated secondary schools. The service gradually spread across the country, only to recede 
during the Great Depression and re-emerge after World War II (Jackson, Walsh, \& Cohen, 2005). Guidance and counselling services really took hold in the USA in response to the 1957 Russian launch of Sputnik when the federal government decided to dramatically increase the number of scientists and mathematicians in the workforce (Bryant, 2006). Ongoing expansion took place in the 1960s to support civil rights legislation. During this time guidance and counselling service also began to take root in other developed countries, chiefly the United Kingdom (UK) (Bondi, 2004; Dryden, Mearns, \& Thorne, 2000), Canada and Australia (McMahon, 2007). Furthermore university guidance and counselling courses were established and formal qualifications became a requirement of the profession.

Throughout the 1970s and 1980s the school guidance counsellor became a more accepted part of the school staff. The focus areas managed by guidance and counselling continued to expand to include personal and social issues, and to more explicitly cater for the needs of all students across the full age and ability range. In the 1990s professional standards were developed worldwide and since 2000, renewed attention has been focused on finding ways to help close the gap between the haves and have not's (Clemens, Carey, \& Harrington, 2010; Gysbers, 2010; Thompson, 2012). One such way has been through the adoption of a transformative paradigm approach - purposively employs research methods from different research methodologies to conduct research that promotes social justice (Mertens, 2007). This approach is relevant for guidance and counseling services in developing countries such as PNG; because it is able address the needs of vulnerable students.

My work over the past twenty years has provided me with a very comprehensive overview of guidance and counselling service in PNG schools. In PNG the term school guidance and counselling refers to a process of helping individuals to understand themselves by discovering their own needs, interests and capabilities in order to formulate their own goals and make plans for realizing those goals (Calaguas, 2012). In reality, guidance and counselling services in PNG are grossly inadequate with about 17 guidance officers looking after the guidance and counselling needs of approximately 1.5 million students (PNG Department of Education, 2004). As a result, very little is done for students in elementary and primary schools with the majority of the services organised around grades 11 and 12 career guidance.

Guidance and counselling services in PNG are either completely missing or are provided by teachers or ancillary staff who have had little or no training in the area. This lack of services is occurring in a context of rapid change where the number of children attending school is growing substantially. More children are staying at school for longer periods of time now compared to the situation before the new education reform (PNG Department of Education, 2008). At the same time there has been a dramatic rise in serious social issues: drug and alcohol abuse, health problems including HIV/AIDS, domestic violence, poverty, teenage pregnancy, ethnic clashes and inter-school fights (Philemon, 2012; Postcourier, 2013; Ukaha, 2013). There is therefore an urgent need for guidance and counselling services to undergo a transformation to help ensure that these services are able to adequately and more equitably meet the educational, vocational, social and emotional needs of the students. Of course the difficulty is how this challenge might be realistically achieved. It is for this reason that I have chosen to employ a transformative paradigm approach for my research. 


\section{Rationale for This Study}

PNG is a developing country characterised by issues such as agricultural based economy with approximately 80 percent of its population living in rural areas; approximately 30 percent in extreme poverty measured at less than US\$1 a day (Jha \& Dang, 2010). Its population is approximately 7 million speaking more than 800 languages; PNG is arguably the most culturally diverse nation on earth. The annual population growth rate is between 2.3 and 2.7, with 40 percent of the population under the age of 20 and about 55 percent unable to read or write (PNG Department of Education, 2004). Furthermore PNG has an increasing unemployment rate and a very low human development index of 153 out of 187 (Jha \& Dang, 2010; UNESCO, 2010). The total land area of 463,840 square kilometres comprises a mixture of tropical rain forest, mountainous terrains, savannah grass plains, swamps and numerous islands. It is also amongst the most rural and geographically isolated, with many remote villages only accessible by boat, foot or air. A serious lack of infrastructure throughout the country often deprives people of even the most basic health and education services (World Bank, 2010).

PNG has been energetically focusing on achieving Universal Basic Education by increasing the number of elementary, primary and secondary schools throughout the country with the goal of achieving 73\% enrolment by 2015, up from 53\% in 2007 (AusAID, 2012). Only 1.2 million of 2 million school age children go to school while the rest remain in the village for various reasons according to the National Education Board Annual Report (2008). The country's plan to improving the situation is evident in the PNG Government's Vision 2050 National Strategic Plan (PNG Government, 2009) and PNG Department of Education National Plan for Education 2005 - 2014 (PNG Department of Education, 2004). Both policies which PNG developed in conjunction with requirements from the World Bank, UNESCO (Limage, 2007) and AusAID (AusAID, 2003) aspire towards producing healthy, educated and skilled citizens. The policies state that integral human development is vital for eradicating poverty, improving personal health, reducing unemployment and promoting gender equality. If the Government wanted to achieve its goals, it should consider developing an adequate comprehensive guidance and counselling services for the schools. The services will guide and direct all students in their personal, social, emotional and career development needs and ensure that each individual reach a full potential to positively contribute to his personal wellbeing as well as the community he identifies with.

\section{Research Focus}

\section{Transformative Paradigm Framework}

This study will use the transformative paradigm framework to explore whether students with different needs are adequately addressed by the guidance and counselling service provided in PNG schools. Mertens (2007) described transformative “... framework for addressing inequality and injustice using culturally competent, mixed methods strategies” (p. 212). The transformative paradigm guides researchers in the clarification of their systems related to ontology (the nature of reality), axiology (the role of ethics), epistemology (the relationship between knower and the known), and methodology (a research paradigm). Rather than coming from the current political, socio-cultural, economic reality where some are privileged, the transformative paradigm purposively employs research methods from different research 
methodologies to conduct research that promotes social justice. Qualitative and quantitative research methodologies are combined in ways that ensure the perspectives of those who are disadvantaged and marginalised. Research using transformative paradigm therefore aims to establish a foundation for social change that will address complexities of those being researched (Mertens, 2010b).

The transformative approach was chosen because it is applicable for investigating guidance and counselling services in both developed and developing countries. The services in developing countries have tended to lag far behind those in the developed world with vulnerable individuals being the most disadvantaged. For example, in PNG many students with special learning needs do not have access to specialist care-givers because systems are not in place to cater for them. Therefore the data from this study would assist in developing guidance and counselling services that would account for the needs of all students with different learning needs. That the services are culturally appropriate and socially just while being in line with the world best practices (Henderson \& Gysbers, 2005).

The current guidance and counselling services in PNG schools which was introduced in the early 1970s still focuses on the traditional aspects of guidance: educational, vocational and personal. However, at the global scene guidance and counselling in schools has witnessed dramatic and irreversible changes in the way services are conceptualised and delivered (Gysbers \& Henderson, 2006). The focus is on comprehensive guidance and counselling services to ensure that holistic programs are available for students learning and development benefits. The services must help to more adequately prepare each student to face the challenges of a rapidly evolving work environment within a newly developing complex multicultural society (Calaguas, 2012). Therefore, it is appropriate that PNG must plan for comprehensive guidance and counselling services, which would contribute towards achieving the goals of the PNG Government:

Our (PNG) vision is integral human development achieved through an affordable education system that appreciates Christian and traditional values, and that prepares literate, skilled and healthy citizens by concentrating on the growth and development of each individual's viability and character formation, while ensuring all can contribute to the peace and prosperity of the nation. (PNG Department of Education, 2004, p. 17)

\section{Research Questions}

The following three questions will form the bases of the study:

1. What were my subjective experiences when working in guidance and counselling in PNG and how do these fit in with the wider cultural, political and social meanings and understandings?

2. What is the scope and type of guidance and counselling service currently available in PNG schools and how do these compare with those available in Queensland state schools?

3. How could guidance and counselling service in PNG be improved to benefit all students? 


\section{Research Methods}

In my research I plan to conduct three separate but related research studies. Each study will be based on one of the above stated research questions. These studies will combine to provide a diversity of values, stances and positions, and “... contain an action agenda for reform that may change the lives of the participants, the institutions in which individuals work or live and the researcher's life” (Creswell, 2009, p. 9). In addition, the use of mixed methods research provides “... the opportunity for presenting a greater diversity of divergent views and ... better inferences” (Tashakkori \& Teddlie, 2003, p. 14). The first study will be an autoethnography in which I investigate my own experiences of working in the area of guidance and counselling in PNG. The second will be a quantitative comparative study in which I use a survey questionnaire to help describe the scope and type of services currently provided in PNG and in Queensland, Australia. Finally the third will be a comparative qualitative study where I will interview eight pertinent individuals in PNG and the State of Queensland about guidance and counselling service in the two countries with a view to exploring how services in PNG will need to change to better meet anticipated future requirements.

\section{Autoethnography: Personal Experience}

The first research question will form the basis of the autoethnography. Autoethnography is an approach to research and writing that seeks to describe and systematically analyse personal experience in order to understand social and cultural experiences (Ellis, Adams, \& Bochner, 2011). It is an autobiographical genre of research in which the subjectivity of the researcher is explicitly taken as the object of enquiry. Autoethnography situates self within a cultural context, moving in and out through one's own experiences. I will answer the first research question engaging autoethnography as described by Ellis \& Bochner (2003):

I start with my personal life. I pay attention to my physical feelings, thoughts, and emotions. I use what I call systematic sociological introspection and emotional recall to try to understand an experience I’ve lived through. Then write my experience as a story. (p. 206)

Although some scholars in the field have criticised autoethnography because of its focus on the self for both method and writing (Sparkes, 2000; Roth, 2008) others support the focus on self (Anderson, 2006; Ellis et al., 2011) because only through autoethnography "some experiences which are ignored, distorted or silenced because of the discomfort they cause, can become known and understood” (Doloriert \& Sambrook, 2012, p. 85). Furthermore, introspection of the self provides the researcher the opportunity to "consider ways others may experience similar epiphanies; they must use personal experience to illustrate facets of cultural experience, and, in so doing, make characteristics of a culture familiar for insiders and outsiders” (Ellis et al., 2011, p. 9).

The process of examining the connection between self and society/culture helps me better understand where I come from and how I got to where I am now. This in turn will enable me to more clearly describe my relationship to others who are similar, different or of opposition. It is hoped that my narrative will enable readers to better understand my socio-cultural background, experience and insights into guidance and counselling service in PNG and thereby provide a valuable platform from which to conduct the second study. The use of autoethnography will affirm my insider-research status of having insight into the system 
(Brannick \& Coghlan, 2007) and being in a position to achieve "understanding in use rather than reconstituted understanding” (Coghlan, 2003, p. 465).

\section{Survey Research}

I will use survey research to investigate the second research question namely: What is the scope and type of guidance and counselling service currently available in PNG schools and how do these compare with those available in Queensland state schools? A survey is an "information collection method to describe, compare, or explain individual and societal knowledge, feelings, values, preferences, and behaviour” (Fink, 2013, p. 2) so it is particularly well suited to the research question. Surveys allow the researcher to collect data by questioning, observing, interviewing (or combination of these) people as they are without altering anything so the emphasis is on the researcher being as unobtrusive as possible, with the goal of collecting data that accurately reflects real conditions (Robson, 2011). For this reason, survey research tends to be quantitative or, as in this research, follows a mixed methods approach where both quantitative and qualitative data are collected.

A survey questionnaire instrument will be designed to gather information relevant to the research question. The instrument will comprise three items; closed, open-ended and Likert scale (Babbie, 2001; Creswell, 2012; Robson, 2011). The questionnaire will cover every aspect of the research purpose in order to provide sufficient information about the scope and types of guidance and counselling service available in PNG and Queensland schools. To determine the appropriateness and usefulness of the specific survey instruments to void any inconsistencies and ambiguity (Robson, 2011) the questions will be pre-tested involving persons in PNG and Queensland who are currently involved in guidance and counselling. In addition, there will be clear instructions and explanations so that the "schedule of questions must be responded in the same order, with the same wording, ... to ensure each subject is responding to the same instrument” (Burns, 2000, p. 257). I will personally supervise the instruments at all research locations to maintain uniformity in administering the questionnaire. The participants' identity and privacy will remain anonymous (Robson, 2011).

There will be about 30 participants engaged in this study. They will come from four schools: a primary school and a high school in Goroka (PNG) and a primary school and a high school in Townsville (Queensland). Other groups included in the study are non-government organisations, churches, and professional groups. and A quantitative sampling method known as convenience sampling (Burns, 2000; Creswell, 2012) will be used to select the participants from each school. This procedure has been adopted because of the researcher's acquaintance with the participants who are willing to contribute; the prior knowledge about guidance and counselling in the two locations, financial constraints and limited duration of the scholarship (Burns, 2000). In order to minimise research bias, reputable participants who are actively engaged in guidance and counselling have been identified so that data collected is useful for the purpose of the study and for external generalizability (Robson, 2011). In addition, the data from the interview research will be used to check for any evidence of bias. (See Table 1 and Table 2 for full list of participants).

The data collected from the survey will be analysed using several methods. Robson (2011) describes analysis of data as "... breaking up of something complex into smaller parts and explaining the whole in terms of the properties of, and relations between, these parts" (p. 
412). Content analysing process involves organising collected data in a systematic approach to see whether it provides answers to the research question. It will involve preliminary organisation of the data under various headings and subjects using various coding, then the inductive process of narrowing data into few themes (Fink, 2013; Lankshear \& Knobel, 2011). The Statistical Package for the Social Sciences (SPSS) computer software will also be used to analyse data from the survey by representing the results in tables and figures and reporting results in a discussion (Burns, 2000; Creswell, 2012).

Table 1: The Goroka Survey Participants

\begin{tabular}{llll}
\hline Officer & Organisation & $\begin{array}{l}\text { Number of } \\
\text { Participants }\end{array}$ & Comments \\
\hline Guidance Officer & $\begin{array}{l}\text { Education } \\
\text { Depart. }\end{array}$ & 16 & $1 \times 21$ provinces \\
$\begin{array}{l}\text { Deputy Principal } \\
\text { school }\end{array}$ & 2 & $1 \times 2$ schools \\
$\begin{array}{l}\text { School } \\
\text { Counsellor }\end{array}$ & school & 2 & $1 \times 2$ schools \\
NGO & NGO & $1 \times 2$ school \\
Chaplain & church & 1 & $1 \times 1$ organisation \\
Total & & 24 & $1 \times 2$ churches \\
\hline
\end{tabular}

Table 2: The Townsville Survey Participants

\begin{tabular}{|c|c|c|c|}
\hline Officer & Organisation & $\begin{array}{l}\text { Number of } \\
\text { Participants }\end{array}$ & comments \\
\hline District Guidance Officer & $\begin{array}{l}\text { Education } \\
\text { Qld. }\end{array}$ & 1 & $1 \mathrm{x}$ 1district \\
\hline Deputy Principal & school & 2 & 1x 2 schools \\
\hline Guidance Officer & $\begin{array}{l}\text { Education } \\
\text { Qld. }\end{array}$ & 4 & 1x 4 schools \\
\hline $\begin{array}{l}\text { Behaviour } \\
\text { Teacher/Counsellor }\end{array}$ & School & 2 & 1x 2 schools \\
\hline Chaplain & Church & 2 & $1 \times 2$ schools \\
\hline Special Service Provider & $\begin{array}{l}\text { Service } \\
\text { provider }\end{array}$ & 2 & $\begin{array}{l}1 \times 2 \text { service } \\
\text { providers }\end{array}$ \\
\hline Total & & 13 & \\
\hline
\end{tabular}

\section{Interview Research}

The qualitative survey interview method will be engaged to collect data for the third research question: How could guidance and counselling service in PNG is improved to benefit all students? Interviewing as a research method is widely used in social research and is characterised by the researcher asking questions and receiving answers from the people being interviewed (Robson, 2011; Yin, 2011). Yin (2011) stated that the basic objective of qualitative interviewing is, “... to pursue an interest in understanding the lived experience of other people and the meaning they make of their experience” (p. 134). This is achieved 
through a conversational mode which presents the opportunity for two-way interactions between the researcher and a participant or even a group of people. The researcher maintains rapport between the parties through respect, understanding and confidentiality while keeping a healthy conversation through being neutral, with good posture and a healthy conversation (Creswell, 2012; Fink, 2013; Robson, 2011).

The interviews will be conducted in Goroka and Townsville respectively involving eight pertinent individuals: four at each study location (see Table 3 and Table 4 for full list of participants). It will be a 40 minute one-on-one semi-structured interview with the aid of an interview guide. With the permission of the interviewees; the interview sessions will be recorded. Notes will be taken so that important details are not lost as well as for transcribing purposes (Robson, 2011). The participants have been specifically identified because of their association with guidance and counselling service in various capacities such as school counsellors and administrators. They are expected to provide well-informed responses about guidance and counselling service in the two countries with a view to exploring options towards developing an effective comprehensive service which will meet the needs of every student in PNG.

Townsville has been identified has the location for study for several reasons; 1) Australia's historical influences in PNG politically and educationally. PNG's education system was basically designed around Queensland and New South Wales curriculum until changes were made after independence (Waiko, 2007). However, the Guidance and Counselling Branch continues to utilise Australian expertise to develop its programs. 2) Queensland's proximity to PNG has enabled closer professional relationship among guidance officers in exchanging ideas and attending workshops in Queensland in recent years. And, 3) the rapport already established with the possible participants as a result of the researcher based at James Cook University in Townsville. In addition, other related costs for travel and accommodation are greatly minimised.

The information collected from the qualitative interview will be analysed using coding; i.e. classifying material into themes, issues, topics and concepts (Burns, 2000). The NVivo software package (QSR International, 2012) will also be engaged to assist in analysing the interview data.

Table 3: The Goroka Interview Participants

\begin{tabular}{|c|c|c|c|}
\hline Officer & Organisation & $\begin{array}{l}\text { Number of } \\
\text { Participants }\end{array}$ & Comments \\
\hline Director & $\begin{array}{l}\text { Guidance \& Counselling } \\
\text { Branch }\end{array}$ & 1 & $1 \times$ 1nation \\
\hline $\begin{array}{l}\text { Guidance } \\
\text { officer }\end{array}$ & Education Department & 1 & 1x 1 province \\
\hline $\begin{array}{l}\text { Deputy } \\
\text { principal }\end{array}$ & School & 1 & $1 \mathrm{x} 1$ school \\
\hline $\begin{array}{l}\text { Executive } \\
\text { member }\end{array}$ & $\begin{array}{l}\text { Guid. \& Counselling } \\
\text { Association }\end{array}$ & 1 & $1 \times 1$ association \\
\hline & Total & 4 & \\
\hline
\end{tabular}


Table 4: The Townsville Interview Participants

\begin{tabular}{llll}
\hline Officer & Organisation & $\begin{array}{l}\text { Number of } \\
\text { Participants }\end{array}$ & comments \\
\hline $\begin{array}{l}\text { Senior guidance } \\
\text { officer }\end{array}$ & Education Queensland & 1 & 1 x 1district \\
$\begin{array}{l}\text { Guidance officer } \\
\text { Deputy principal } \\
\text { Executive member }\end{array}$ & $\begin{array}{l}\text { Education Queensland } \\
\text { School }\end{array}$ & 1 & $1 \times 1$ cluster \\
& $\begin{array}{l}\text { Guid. \& Counsel. } \\
\text { Association }\end{array}$ & 1 & 1 x 1 school \\
& $\quad$ Total & 4 & 1 x 1 association \\
\hline
\end{tabular}

\section{Conclusion}

In view of the visions and goals of the PNG National Government's Vision 2050 and the PNG Department of Education National Plan for Education 2005 - 2014, the current socioeconomic trend and the absence of any research on the current practices of guidance and counselling services in the schools, it is appropriate to conduct this study. Some of the possible benefits of this research include:

It is the intension of this study to have an impact on both the Government's and Department of Education's integral human development plan to achieving a smart, wise, fair, and happy society through an affordable education system that prepares literate, skilled and healthy citizens (PNG Department of Education, 2005; PNG Government, 2009). The study would assess the current guidance and counselling service in the schools and make recommendations to develop a comprehensive guidance and counselling service in order to embrace the needs of every student. Furthermore, the school system is a vital mechanism for integral human development and the expansion of an effective comprehensive guidance and counselling service will sustain the Government's vision.

The result of this study has the potential to influence the Guidance and Counselling Branch to revise its scope of programes and services so that it caters for students holistic needs. Currently the focus of the Branch is towards educational guidance and career development with little attention for areas such as emotional, spiritual, inclusive education, and students with special needs. In addition, the guidance and counselling programs in PNG schools have been designed and in practice for over forty years. The literature (Anctil, Smith, Schenck, \& Dahir, 2012; Henderson \& Gysbers, 2005; Schofield, 2013) indicates that there have been major changes in guidance and counselling service in which other aspects of students' learning, and well-being are considered vital toward academic achievements. Therefore, it is crucial that this study should assess and assert the need to review in order to develop a plan for a comprehensive and effective set of guidance and counselling service in PNG schools.

The findings of this study will enable all stakeholders to be effective partners of the guidance and counselling service in the schools (Gysbers \& Henderson, 2001). The success and sustainability of the services depend on the perception and commitment of the administrators, parents, students and the community. Therefore, the result of this study is expected to change the stakeholders' perceptions of the value of guidance and counselling service in the PNG schools, and appreciate the importance of the service in the whole philosophy of education. 
In addition, according to Burns (2000), educational leaders and practitioners are required to make decisions daily which have tremendous impact on the type and quality of education made available to clients. Therefore, it is an optimal opportunity for this study to present data for stakeholders' consideration.

The outcome of this study would realise the following changes in guidance and counselling services in Papua New Guinea schools:

a) Identify systems, processes and strategies to develop a comprehensive guidance and counselling service that are socially just and meet every student's need,

b) Develop guidance and counselling service that will sustain the PNG government's integral human development policies, and

c) Promote development of guidance and counselling service in line with world practices.

\section{Works Cited}

Anctil, T. M., Smith, C. l. K., Schenck, P., \& Dahir, C. A. (2012). Professional school counselors' career development practices and continuing education needs. The Career Development Quarterly, 60(2), 109-121. doi: 10.1037/0022-0167.53.2.272 10.5330/PSC.n.2010-11.253

Anderson, L. (2006). Analytic autoethnography. Journal of Contemporary Ethnography, 35(4), 373-395. doi: 10.1177/0891241605280449

Babbie, E. (2001). The practice of social research (9th ed.). Belmont, CA: Wadsworth/Thomson Learning.

Bondi, L. (2004). The professionalisation of counselling in the United Kingdom. Health Place, 10(4), 319-328. doi: 10.1016/j.healthplace.2004.08.003

Brannick, T., \& Coghlan, D. (2007). In defence of being "native". The case for insider academic research. Organisational Research Methods, 10, 59 - 74.

Bryant, J. A. (2006). Mission creep: The Federal government and America's schools. Education research and Perspectives, 33(1), 84 - 104.

Burns, R. B. (2000). Introduction to research methods. (4th ed.). Frenchs Forest, NSW: Longman.

Calaguas, G. M. (2012). Academic achievement and school ability: implications for guidance and counselling programs. Journal of arts, science \& commerce, 2(3), 49 -55.

Clemens, E. V., Carey, J. C., \& Harrington, K. M. (2010). The School counseling program implementation survey: initial instrument development and exploratory factor analysis. Professional School Counseling, 14(2), 125-134.

Coghlan, D. (2003). Practitioner research for organizational knowledge; Mechanistic and organistic-oriented approaches to insider action research. Management Learning, 34, 451 - 463.

Creswell, J. W. (2009). Research design: Qualitative, quantitative, and mixed methods approaches (2nd ed.). Los Angeles: Pearson.

Creswell, J. W. (2012). Educational research: Planning, conducting, and evaluating quantitative and qualitative research (4th ed,). Boston, MA:Pearson. 
Doloriert, C., \& Sambrook, S. (2012). Organisational autoethnography. Journal of Organizational Ethnography, 1(1), 83-95. doi: 10.1108/20466741211220688

Dryden, W., Mearns, D., \& Thorne, B. (2000). Counselling in the United Kingdom: Past, present and future. British Journal of Guidance \& Counselling, 28(4), 467 - 483.

Ellis, C., Adams, T. E., \& Bochner, A. P. (2011). Autoethnography: an overview. Historical Social Research, 36(4), 273 - 290.

Ellis, C., \& Bochner, A. P. (2003). Autoethnography, personal narrative, reflexivity research as a subject. In N. K. Denzin, \& Y. S. Lincoln (eds), Collecting and interpreting qualitative materials (pp.199-258).Thousand Oaks, Calif.: Sage.

Fink, A. (2013). How to conduct surveys: A Step by step guide (5th ed.). Thousand Oaks,CA:Sage.

Gysbers, N. C. (2010). Remembering the past, shaping the future: a history of school counseling. Alexandria, VA.: American School Counselor Association.

Gysbers, N. C., \& Henderson, P. (2001). Comprehensive guidance and counselling programs: a Rich history and bright future. Professional School Counseling, 4(4), 246 - 256.

Gysbers, N. C., \& Henderson, P. (2006). Developing \& managing your school guidance and counseling program. (4th ed.). Alexandria, VA.: American Counseling Association.

Henderson, P., \& Gysbers, N. C. (2005). Implementing comprehensive school guidance programs : critical leadership issues and successful responses. Austin, TEX.: CAPS Pr

Jackson, J. H., Walsh, M. E., \& Cohen, K. M. (2005). School counselling. Encyclopedia of Applied Developmental Science, 2, 953-955.

Jha, R., \& Dang, T. (2010). Vulnerability to Poverty in Papua New Guinea in 1996. Asian Economic Journal, 24(3), 235-251. doi: 10.1111/j.1467-8381.2010.02038.x

Lankshear, C., \& Knobel, M. (2011). A Handbook for teacher research: from design to implementation. Maidenhead Berkshire: Open University Press.

Limage, L. J. (2007). Organizational challenges to international cooperation for literacy in UNESCO. Comparative Education, 43(3), 451-468. doi: 10.1080/0305006070155647.

Mason, E. (2010). Leadership practices of school counselors and counseling program implementation. National Association of Secondary School Principals. NASSP Bulletin, 94(4), 274-285.

McMahon, M. (2007). Career counselling in Australia. International Journal of Psychology, 41(3), 174-179. doi: 10.1080/00207590544000167

Mertens, D. M. (2007). Transformative paradigm: Mixed methods and social justice. Journal of Mixed Methods Research, 1(3), 212-225. doi: 10.1177/1558689807302811

Mertens, D. M. (2010a). Philosophy in mixed methods teaching: the transformative paradigm as illustration. International Journal of Multiple Research Approaches, 4(1), 9 - 18.

Mertens, D. M. (2010b). Transformative mixed methods research. Qualitative Inquiry, 16(6), 469-474. doi: 10.1177/1077800410364612

Policy Branch. (2008). National Education Board Annual Report, Waigani: Education Printer.

Philemon, O. (2012). Urban gangs - a social crisis. The National Newspaper.

PNG Department of Education. (2004). National education plan 2005-2014. Waigani: Education Printer.

PNG Department of Education. (2005). Annual report: Prosperity through self reliance. Port Moresby:Education Printer.

PNG Government. (2009). PNG Vision 2050. Port Moresby: Govenment Printer.

Postcourier. (2013). Student killed. Post Courier(29th May).

QSR International. (2012). The NVivo workbook. Brisbane: QSR. 
Robson, C. (2011). Real world research (3rd ed.). Chichester, West Sussex: Wiley.

Schofield, M. J. (2013). Counseling in Australia: Past, present and future. Journal of Counseling and Development., 91(2), 234 - 239.

Tashakkori, A., \& Teddlie, C. (2003). Major issues and controversies in the use of mixed methods in the social and behavioral sciences. In A.Tashakkori \& C.Teddlie (Eds.), Handbook of mixed methods in social \& behavioral research.Thousand Oaks, Calif. : Sage.

Thompson, R. (2012). Professional school counselling: Best practices for working in the schools (3rd ed.).New York, NY: RoutledgeTaylor \& Francis Group.

Ukaha, J. (2013). Lae suspends school classes. The National Newspaper, 29th May.

UNESCO-IBE. (2011). World Data on Education 2010/11(7th ed.). Papua New Guinea. Retrieved from http://www.ibe.unesco.org .

UNESCO. (2010). World Data on Education 2010/11(7th ed.). Papua New Guinea. Retrieved from http://www.ibe.unesco.org . UNESCO Report 2010/11.

Waiko, J. D. (2007). A Short history of Papua New Guinea (2nd ed.). Melbourne: Oxford University Press.

World Bank. (2010). Country assistance strategy progress report for PNG for the period FY08 - FY11. Washington DC: The World Bank. http://documents.worldbank.org/curated/en/2010/03/12041056/papua-new-guineacountry-assistance-strategy-progress-report-period-fy08-fy11. World Bank Report.

Yin, R. K. (2011). Qualitative research from start to finish.New York, NY:Guilford Press. 